\title{
Decline in suspended sediment concentration delivered by the Changjiang (Yangtze) River into the East China Sea between 1956 and 2013
}

\author{
Zhijun Dai ${ }^{1,2}$, Sergio Fagherazzi ${ }^{2}$, Xuefei $\mathrm{Mei}^{1} \&$ Jinjuan Gao ${ }^{1}$ \\ ${ }^{1}$ State Key Lab of Estuarine \& Coastal Research, East China Normal University, Shanghai, China \\ ${ }^{2}$ Department of Earth and Environment, Boston University, USA \\ Corresponding author \\ Zhijun Dai \\ Email: zjdai@sklec.ecnu.edu.cn; \\ Tel: +86 2162233458 ; \\ Fax: +862162546441
}

\begin{abstract}
The temporal evolution of suspended sediment concentration (SSC) in a river debouching into the ocean provides vital insights into erosion processes in the watershed and dictates the evolution of the inner continental shelf. While the delivery of sediment from rivers to the ocean has received special attention in the recent past, few studies focused on the variability and dynamics of river SSC, especially in the Changjiang (Yangtze) river, China, the longest river in Asia. Here, variations in SSC delivered by the Changjiang River to the East China Sea and possible causes of its variability were detected based on a long-term time series of daily SSC and monthly water discharge measured at the Datong gauging station. The SSC data are further compared to a hydrological analysis of yearly precipitation covering the entire catchment. The results indicate the presence of a decline in SSC in the period 19562013, which can be divided into three phases: (i) high SSC $\left(0.69 \mathrm{~kg} / \mathrm{m}^{3}\right)$ in the wet season and low SSC $\left(0.2 \mathrm{~kg} / \mathrm{m}^{3}\right)$ in the dry season from 1956 to 1970; (ii) relative high $\operatorname{SSC}\left(0.58 \mathrm{~kg} / \mathrm{m}^{3}\right)$ in the wet season and low $\operatorname{SSC}\left(0.15 \mathrm{~kg} / \mathrm{m}^{3}\right)$ in the dry season from 1971 to 2002; and (iii) low SSC $\left(0.19 \mathrm{~kg} / \mathrm{m}^{3}\right)$ in the wet season and very low SSC (0.09 $\mathrm{kg} / \mathrm{m}^{3}$ ) in the dry season after 2002 . These three periods have a mean yearly SSC values of $0.62,0.42$, and $0.18 \mathrm{~kg} / \mathrm{m}^{3}$, respectively. Compared with $1956-1970$, the slope of the rating curve between SSC and water discharge decreased, respectively, by $2 \%$ and $30 \%$
\end{abstract}


during the period 1971-2002 and 2002-2013. Soil erosion, dam construction, and banks reinforcement along the Changjiang River are the main causes of SSC variations. Fluctuations in water discharge are also controlling the SSC long-term variations. Specifically, from 1956 to 1970, the effect of soil erosion overrules that of dam impoundment, which is likely responsible for the high SSC; during the period 19702002, the influence of dam impoundment increases while that of soil erosion decreases, which together produce a small reduction in SSC. Since 2002, the impact of soil erosion further decreases and large-scale sediment trapping behind the Three Gorges Dam is responsible for the occurrence of extremely low SSC. The results presented herein for the Changjiang River can inform a better management strategy of sediment resources and water quality for both the river and the coast. Our conclusions can be well applied to other rivers discharging in the ocean subject to similar human activities.

Keywords: suspended sediment concentration; runoff; anthropogenic activities; Changjiang (Yangtze) River 


\section{Introduction}

Sediment transport from rivers to the ocean has been seen as a vital pathway of material transfer on the Earth surface, playing a key role in global biogeochemical cycles (Dagg et al., 2004; Walling, 2006; Kettner et al., 2007; Liu et al., 2007; Huang, 2010). However, the river sediment supply to the ocean has been strongly regulated by human structures in recent decades, leading to a drastic decrease in flux as a result of significant alterations of the estuarine and river environment (Milliman and Boyle, 1975; Syvitski et al., 2005; Milliman and Farnsworth, 2011; Allison et al., 2012). As a result, in recent years attention has increased on the reduction of fluvial transport of suspended sediment into the ocean (Horowitz, 2003; Syvitski et al., 2005).

Some studies indicate that dams have a serious impact on the decrease of suspended sediment discharge (SSD) in rivers (Vörösmarty et al., 2003; Walling and Fang, 2003; Dai et al., 2011c; Milliman and Farnsworth, 2011). A typical example is the reduction of SSD of the Nile River, Egypt. A 98\% decrease in SSD into the Nile delta was measured after the construction of the Aswan High Dam in 1964 (Frihy et al., 1998). Similarly, the Colorado River has lost almost $100 \%$ of its sediment load since 1941, and the SSD of the Danube River in Europe has decreased by 35\% in the last century (Milliman and Farnsworth, 2011). The Changjiang (Yangtze) River, China, was discharging into the estuary a mean yearly SSD of about $433 \times 10^{6} \mathrm{t} / \mathrm{y}$ between 1950 and 2000. Since 2003 it has experienced nearly $70 \%$ reduction in SSD from the construction of the Three Gorges Dam (TGD; Dai et al., 2014).

Reduction in SSD to the ocean can be attributed to several anthropogenic activities, such as soil and water conservation, revetment of river banks, and sediment erosion control programs (Walling and Fang, 2003). A recent study has pointed out that river engineering has caused a decline in SSD in the Mississippi River system in the period 1940-2007 (Meade and Moody, 2010). In the Yellow River, China, soil conservation practices are responsible for $40 \%$ of the total SSD decrease in recent years (Wang et al., 2007). Kronvang et al. (1997) showed that in an arable catchment, most of the annual sediment transport usually takes place during few events, and thus the short-term dynamics of storm events are important in sediment delivery. Recently, Dadson et al. (2003) indicated that the storm-driven runoff variability is responsible for large fluctuations in SSD in a mountainous river in Taiwan. A more recent study revealed that the frequent floods in the Wadi Sebdou catchment, Algeria, accounted for $64 \%$ of 
the total sediment flux (Megnounif et al., 2013). Since the amount of sediment discharged from rivers to the sea directly impacts the morphology of estuaries and deltas, considerable efforts have been focused on understanding the dynamics of SSD.

However, SSD is a product of suspended sediment concentration (SSC) and water discharge (Phillips et al., 1999). Changes of river SSC should be one of the important factors determining the amount of SSD reaching the ocean. Variations in riverine SSC can induce alterations of local species composition (Quinn et al., 1992), fish mortality (Greig et al., 2005; Heywood and Walling, 2007), restriction of periphyton growth (Yamada and Nakamura, 2002), and an increase in the delivery of phosphorus (Ballantine et al., 2009; Quinton et al., 2001). While the delivery of suspended sediments from rivers to the ocean has received particular attention in recent years, the variability and dynamics of suspended sediment concentration (SSC) require a more indepth analysis.

Many studies indicate that SSC is a key variable in a river because it is directly related to contaminant transport, water quality, reservoir sedimentation, silting, soil erosion, and loss and has clear ecological and recreational impacts (Walling, 1977; Ferguson, 1986; Horowitz et al., 2001; Rovira and Batalla, 2006). Some studies have revealed that catchment topography, geology, and climate could determine the quantity and quality of suspended sediment in rivers (Walling, 1977; Wass and Leeks, 1999). Other studies have linked SSC to runoff, land use, construction activities, hillslope, and channel erosion (Walling et al., 1999; Rondeau et al., 2000; Siakeu et al., 2004). So far, research on variations in riverine SSC is mainly based on the discharge-SSC relationship, which is used to gain a comprehensive understanding of river processes (Sickle and Beschta, 1983; Walling, 1997; Steegen et al., 2000; Terfous et al., 2001; Horowitz, 2003; Xu and Milliman, 2009; Eder et al., 2010; Megnounif et al., 2013).

However, traditional relationships between SSC and discharge are empirical and usually variable in time, thus causing a large scatter of SSC data for a given discharge and failing to explain short- and long-term hysteresis effects (Eder et al., 2010). The relationship between SSC and water discharge is complex because of the many factors controlling it, such as snowmelt, volcanic activities, climate variability, catchment geology, and anthropogenic activities (Mouri et al., 2014). For example, a recent study found that floods can substantially alter the relation between discharge and SSC in the Mississippi River (Horowitz, 2003). By far, most studies on SSC behavior were based on annual or monthly mean data and discontinuous water sampling, thus failing to 
address the variability and dynamics of SSC in streams. We advocate that daily SSC data are necessary to understand how and to what degree riverine hydrological processes are affected by natural and human drivers, especially in the Changjiang River, China. The Changjiang River is the longest river in China with a catchment area of 1.8 $\times 10^{6} \mathrm{~km}^{2}$. The river can be divided into two parts: the upper stream above the city of Yichang, and the mid-lower stream from Yichang to the ocean (Fig. 1). The geomorphology of the Changjiang River basin is characterized by mountains and hills in the upper-stream area and extensive fluvial plains with numerous lakes in the midlower reaches (Chen et al., 2007). The annual water discharge and SSD at the beginning of the estuary was high between 1950 and 2000, with an average value of $905.1 \times 10^{12}$ $\mathrm{m}^{3} / \mathrm{y}$ and $433 \times 10^{6} \mathrm{t} / \mathrm{y}$, respectively (BCRS, 2001). However, since the TGD (the largest dam in the world) was constructed in the upper stream in 2003, the SSD into the Changjiang estuary has decreased nearly 70\% (Dai et al., 2014; Yang et al., 2015). Such a large decline in a relatively short period has received much attention from the scientific community (Xu and Milliman, 2009; Chen et al., 2010; Dai et al., 2014; Yang et al., 2015). A number of studies focused on the yearly changes in SSD from 1951 to 2000s (Yang et al., 2002; Gao and Wang, 2008), on the fate of suspended sediments delivered to the East China Sea (Liu et al., 2007), on the many impacts of such a decline in SSD (Yang et al., 2015), on the relation between SSD and water discharge (Xu and Milliman, 2009), and on the effects of extreme droughts on SSD (Dai et al., 2011a).

Clearly, previous research on the Changjiang River mainly focused on SSD variations and related consequences on the basis of monthly or yearly hydrological data. The SSD from the Changjiang River to the sea is estimated through water discharge and SSC; however, the impact of dam impoundment on water discharge is much less than SSD (Xu and Milliman, 2009). Compared to SSD, the riverine SSC is more sensitive to the influence of natural forces and human activities. Dams along the Changjiang River, especially the TGD, have decreased the SSD reaching the sea, but have had an insignificant impact on water discharge (Dai et al., 2015). This means that SSC, the other determinant of SSD, is likely to have decreased significantly. However, little work was carried out on the variations of daily SSC in the lower reaches of the Changjiang River. Similarly, no study has yet been carried out to relate the impacts of the TGD on the relationship between daily water discharge and SSC (i.e., the rating curve), which directly influences the estimation of SSD flowing into the sea. Moreover, 
variations in SSC directly affect ecosystems and recreational environments (Walling, 1977; Ferguson, 1986; Horowitz et al., 2001; Rovira and Batalla, 2006). The dynamics of daily SSC values in the Changiiang River should deserve the same level of attention devoted to the annual SSD flowing to the sea. Accordingly, the purposes of this study are (i) to analyze the characteristics of daily SSC in the Changjiang estuary from 1956 to 2013; (ii) to detect the relationship between SSC and water discharge; and (iii) to discern the possible factors affecting SSC variations in the Changjiang estuary from 1956 to 2013.

\section{Material and methods}

The Datong station, located at the tidal limit of the Changjiang estuary at a distance of around $640 \mathrm{~km}$ from the ocean, is a key hydrological station that records the discharge of about $95 \%$ of the Changjiang River catchment. The data collected at this station thus represent the total water discharge and SSD input to the Changjiang estuary (Dai et al., 2011b). Daily measurements of SSC and water discharge have been carried out by the Changjiang River Water Conservancy Committee (CRWCC, 2002), Ministry of Water Conservancy of China (Fig. 1). Precipitation data across the Changjiang basin from 1956 to 2012 were collected by the Weather Information Centre, Weather Bureau of China. Daily water discharge is available from 1956 to 2013, while the yearly mean SSC and water discharge from 1956 to 2013 were obtained from BCRS (2014). Daily SSC are available from 1956 to 2013 except 1988, 1993-1997. Furthermore, variations in the capacity of all reservoirs from 1950 to 2002 and accretion data behind the TGD from 2003 to 2013 are provided by the Changjiang River Water Resources Commission of the Ministry of Water Resources, China (www.cjw.gov.cn).

To discern daily variations in SSC within given years, hydrological coefficient of variation $(\mathrm{Cv})$ and standard deviation were calculated by the Moment method (Greenwood et al., 1979). According to the IPCC Fourth Assessment Report, an extreme hydrological event can be defined as the occurrence of a value of a weather or climate variable above the 75th (or below the 25th) percentile (IPCC, 2007). Specifically, the year with annual precipitation greater than the 75 th percentile is set as a flood year, while that with yearly precipitation less than the 25 th percentile is defined as a dry year. In this study, the 25th and 75th percentiles of daily SSC are selected as thresholds. The 25 th percentile represents a low SSC event, while the 75 th 
percentile represents a high SSC event. Here we use the calculation methods of percentile values presented in Bonsal et al. (2001).

A simple frequency analysis was applied to diagnose daily variations in SSC. Daily water discharge was regressed against daily SSC using a power law, thus obtaining the following sediment rating curve:

$$
Q_{s}=\mathrm{a} Q_{w}^{b}
$$

where $Q_{s}$ is the SSC, $Q_{w}$ is water discharge, $a$ and $b$ are constants (the slope and the intercept in a log-log plot; Mouri et al., 2014).

\section{Results}

\subsection{Changes in yearly SSC}

The 25th and 75th percentiles of yearly SSD and SSC during the period 1956-2013 are obtained through the method of Bonsal et al. (2001). The SSD and SSC are divided into three periods according to the 25 th and 75 th percentile indices. Specifically, yearly SSD and SSC greater than the 75th percentile mainly occurred before 1970 with several in the 1980s (Figs. 2A, 2B); yearly SSD and SSC smaller than the 25th percentile occurred mainly after 2003. Compared to yearly SSD, yearly SSC can be better divided into the three periods.

Linear regression analysis is further applied to the yearly SSD and SSC over the three periods. In the first period between 1956 and 1970, SSC is stable with a slight downward trend, while SSD indicates a tendency to increase. In the second period between 1971 and 2002, SSD and SSC present declining trends, with SSC displaying a greater regression slope. In the third period between 2003 and 2013, the yearly SSC falls faster than the yearly SSD, with a decrease rate higher than in the period between 1971 and 2002.

Moreover, SSD in flood years (such as 1964, 1973, 1983, 1998, and 2010) are significantly higher than in other years. However, a similar pattern is not observed in the SSC data. For instance, annual SSC in the flood year 1998 is only $0.32 \mathrm{~kg} / \mathrm{m}^{3}$. Moreover, SSD in the drought years of 1963 and 1978 is low while SSC is high. Therefore, variations in yearly SSC are not related to variations in SSD.

Yearly 25th percentiles of SSC present a clear decreasing trend at a significant level of 0.01 (Fig. 4A). It means that low SSC occurred more frequently, with more days having an SSC below $0.2 \mathrm{~kg} / \mathrm{m}^{3}$. However, the 75th percentiles have been declining faster than the 25 th percentiles (Fig. 3B). Moreover, the variation coefficient, standard 
deviation, and the maximum SSC show a clear decreasing trend at the significance level of 0.01 (Figs. 3C, 3D, 3E). This indicates that variations in daily SSC within a year have diminished between 1956 and 2013.

Taken altogether, yearly SSC data indicate periodical declines, which can be divided into three stages based on the 75th and 25th percentile: high SSC between 1956 and 1970, medium SSC between 1971 and 2002, and low SSC between 2003 and 2013 (Fig. 2B). The mean values of these three periods are $0.62,0.42$, and $0.18 \mathrm{~kg} / \mathrm{m}^{3}$, respectively (Fig. 2B).

\subsection{Frequency distribution of SSC}

By analyzing the maximum SSC in each month of the three periods, we found that the monthly maximum SSC varies seasonally in the periods 1956-1970 and 1971-2002, presenting a seasonal fluctuation from 0.15 to $1.6 \mathrm{~kg} / \mathrm{m}^{3}$ and from 0.12 to $1.3 \mathrm{~kg} / \mathrm{m}^{3}$, respectively. The average monthly maximum SSC during the flood season between 1971 and 2002 is $80 \%$ approximately of that between 1956 and 1970. As for the 20032013 period, the monthly maximum SSC are relatively stable in the range of 0.1-0.4 $\mathrm{kg} / \mathrm{m}^{3}$ (Fig. 5). Accordingly, monthly maximum SSC indicates the presence of a significant difference among the three periods.

Monthly mean SSC in the period 1956-1970 and in the period 1971-2002 presents seasonal characteristics, following the pattern of water discharge and SSD (Figs. 6A, 6B, 6C). Namely, average monthly mean SSC in the flood season from 1956 to 1970 and from 1971 to 2002 are 0.69 and $0.58 \mathrm{~kg} / \mathrm{m}^{3}$, while values in the dry season are 0.20 and $0.15 \mathrm{~kg} / \mathrm{m}^{3}$. During the period 2003-2013, averaged monthly mean SSC in the flood and dry seasons are 0.19 and $0.09 \mathrm{~kg} / \mathrm{m}^{3}$. Notably, that the average monthly mean SSC in the flood season during the period 2003-2013 is just around the amount of that in the dry season during the period 1956-1970. We detect a reduced seasonal change in SSD between 2003 and 2013, but almost no seasonal change in SSC during the same period (Figs. 6A, 6C). The monthly SSC from January to December ranges from around 0.1 to $0.2 \mathrm{~kg} / \mathrm{m}^{3}$ with a negligible difference before and after 2003 (Fig. 6A). On the contrary, the monthly peak value of SSC in August and July are $0.9 \mathrm{~kg} / \mathrm{m}^{3}$ approximately in $1956-1970$ and $0.8 \mathrm{~kg} / \mathrm{m}^{3}$ in $1971-2002$, reaching $<0.3 \mathrm{~kg} / \mathrm{m}^{3}$ after 2003 (Fig. 6A).

We further studied the frequency distribution of daily SSC during the high SSC stage (1956-1970), the medium SSC stage (1971-2001), and the low SSC stage (20022013) with a binning interval of $0.05 \mathrm{~kg} / \mathrm{m}^{3}$ (Fig. 7). We can see that the frequency of 
SSC levels above $1.5 \mathrm{~kg} / \mathrm{m}^{3}$ is more than $1.75 \%$ between 1956 and 1970 (Fig. 7A). The frequency of these events then reduces to $0.58 \%$ between 1971 and 2002, while SSC levels above $1.5 \mathrm{~kg} / \mathrm{m}^{3}$ are not present from 2003 to 2013 (Figs. 7B, 7C). Days with an SSC between 1.0 and $1.5 \mathrm{~kg} / \mathrm{m}^{3}$ are $7 \%$ from 1956 to $1970,4.5 \%$ from 1971 to 2002, and hardly present between 2003 and 2013.The most common SSC values are in the range of $0.1-0.4 \mathrm{~kg} / \mathrm{m}^{3}$ between 1956 and 1970 , representing < $10 \%$ of the total values (Fig. 7A). In the periods 1971-2002 and 2003-2013, the most common SSC values are between 0.1 and $0.15 \mathrm{~kg} / \mathrm{m}^{3}$ with frequencies of about $30 \%$ and $60 \%$, respectively (Fig. 7B). The SSC therefore becomes more uniform in these years.

Taken together, these results indicate the presence of high SSC in the flood season and low SSC in the dry season in 1956-1970, relative high SSC in the flood season and low SSC in the dry season in 1971-2002, and low SSC in the flood season and very low SSC in the dry season after 2003.

\subsection{Relationship between SSC and water discharge}

During the periods 1956-1970 and 1971-2002, the SSC is lower for a given discharge in the rising stage of the flow (June to July) compared to the falling stage (July to September). This result agrees with the findings of Xu and Milliman (2009) (Fig. 8). However, our temporal analysis of SSC-discharge hysteresis leads to more results. The hysteresis in 1971-2002 is weaker than that in 1956-1970 because, for the same level of water discharge, monthly mean SSC in 1971-2002 is significantly less than that in 1956-1970. Moreover, the difference in SCC between rising and falling monthly discharge diminishes in the period 2003-2013 (the loop in Fig. 8 is narrower), indicating that monthly SSC almost has no change.

Rating curves between daily SSC and water discharge are shown in Fig. 9. We find a positive linear correlation in a log-log diagram between daily SSC and water discharge for the three different periods. However, the slope of the rating curve exhibits apparent changes during the three stages, having a value of 1.28 in 1956-1970, 1.26 in 1971-2002, and then dropping to a value of 0.93 in 2003-2013. This means that in the period 1956-2002 extreme events with high discharge are characterized by a much higher SSC. On the contrary, in 2003-2013 the SSC changes less for different discharges.

\section{Discussion}


Long-term variations in SSC in rivers are closely associated to the watershed geology and geomorphology, to changes in hydrological conditions, as well as to various human activities (Yang et al., 2004; Yang et al., 2007; Xu and Milliman, 2009; Mouri et al., 2014). Here we discuss possible long-term drivers that have had an impact on the SSC trends presented herein.

\subsection{Water discharge and SSC}

The water discharge of the Changjiang River is controlled by precipitation in the catchment, which is significantly influenced by the East Asian summer monsoon and by the El Niño-Southern Oscillation (Zhang et al., 2007; Wei et al., 2014). We can observe that a close relation exists between yearly water discharge and yearly precipitation in the Changjiang catchment (Fig. 10A; Zhang et al., 2007; Wei et al., 2014). The discharge of the Changjiang River is mainly generated by precipitation. Sediment discharge increases nonlinearly with discharge, so more sediment is carried by the water at high discharges (Wood, 1977). Therefore, water discharge is an important factor controlling daily SSC.

In the period 1956-2013, neither yearly precipitation in the Changjiang catchment nor the yearly water discharge present a significant trend (Fig. 3), while yearly SSC exhibits a great variation (Fig. 2). Interestingly, flood events that occurred in 1964, 1973, 1983, 1998, and 2010 (Fig. 3B) displayed very different values of SSC (Fig. 11) while all maintained high SSD values (Fig. 2). Specifically, floods in 1964, 1973, and 1983 presented a delay between peak discharge and peak SSC, which is especially obvious in the 1964 flood (Figs. 11A, 11B). The SSC in the 1964 flood is generally $>1 \mathrm{~kg} / \mathrm{m}^{3}$, while in 1973 and 1983 the SSC is $<1 \mathrm{~kg} / \mathrm{m}^{3}$ (Figs. 11A, 11B, 11C). The rating curve discharge vs. SSC also exhibits hysteresis in the periods 1956-1970 and 1971-2002 (Fig. 8). All these results seem to be suggesting that several driving forces other than water discharge affect SSC in these two periods. As for the flood of 1998, the daily SSC has already declined to $<0.6 \mathrm{~kg} / \mathrm{m}^{3}$, even if the SSD is still high (Figs. 2A, 11D). In the flood of 2010 the daily SSC is generally around $0.2 \mathrm{~kg} / \mathrm{m}^{3}$ (Fig. 11E). Neither the 1998 nor the 2010 flood displays the delay between maximum discharge and maximum SSC.

Meanwhile, we can observe that in the drought years of 1963 and 1978, when the SSD flowing into the sea was low, the SSC displayed a series of high sediment concentration events with concentrations up to $2 \mathrm{~kg} / \mathrm{m}^{3}$ (Figs. 12A, 12B). However, in the drought year of 2011, the variations of daily SSC are synchronized with those of water discharge (Fig. 12C). Variations in SSC during floods and droughts indicate that 
SSC is not only affected by water discharge but also by dam operations and soil erosion.

\subsection{Impacts of anthropogenic activities}

Some studies have indicated that changes in SSD in the Changjiang catchment could be caused by deforestation/reforestation, dam construction, and climate change (Dai et al., 2014; Yang et al., 2015). Because SSD is the product of water discharge and SSC, variations in SSC could be more sensitive to human disturbance than those of SSD.

In the first period, between 1956 and 1970, the total reservoir capacity in the catchment is only $28 \times 10^{9} \mathrm{~m}^{3}$ (Fig. 13A). This period is characterized by high SSC discharged from the Changjiang River to the sea. Recent studies estimated that in the 1950s the area of the Changjiang catchment subject to soil erosion was as much as 364 $\times 10^{3} \mathrm{~km}^{2}$ (Shi, 1999; Zhang and Zhu, 2001) because serious deforestation was carried out with a forest cover in the catchment decreasing from $60-80 \%$ before the 1950 s to 22\% in 1957 (Zhang and Zhu, 2001). It means that the Changjiang River could have lost as much as 2.4 billion tons of soil per year, of which $0.8-2.4$ billion tons entering into the main stream with a sediment delivery ratio of 0.3-0.5 (Liang et al., 1998; Shi, 1999). A total of about 12-18 billion tons of sediment was discharged into the main stream in 1956-1970. Therefore, intense soil erosion dominates the SSC in this period, which is far greater than the SSC decrease owing to dam trapping, thus causing continuous deposition in the lower reaches (Dai and Liu, 2013). The SSC displays high values in the dry and flood seasons (Figs. 11A, 12A), which can be explained by soil erosion from deforestation along the Changjiang River. In fact, even a light rain event is likely to carry a great amount of sediment when vegetation cover is reduced.

The total reservoir capacity in the Changjiang catchment has increased approximately 6 times between 1971 and 2002, with respect to the period 1956-1970 (Fig. 13A). Sediment trapping by dams could have potentially resulted in a decrease in SSC between 1971 and 2002. In addition, to mitigate flood hazard, the river levees were increased by 10,000 km from 1991 to 2002 (Fig. 13B). These levees might prevent eroded soils from agricultural fields from reaching the river. Counteracting these potential sediment sinks, land use resulting in soil erosion has increased to $707 \times 10^{3}$ $\mathrm{km}^{2}$ in 2001 in the Changjiang basin because of population increase and large-scale forest reclamation (CRWCC, 2002). Changjiang River watershed lost approximately 2.15-3.6 billion tons of soil in 1971-2002 according to the loss rate of 1985, which 
doubles that of 1956-1970. Compared with 1956-1970, reservoir storage increased by six times in 1971-2002, affecting the riverine SSC, especially during the floods of 1983 and 1998 when SSC decreased significantly (Figs. 11C, 11D). However, in the drought of 1978, the water had a high SSC, indicating that serious soil erosion was still present triggered by moderate rainfalls. Accordingly, Changjiang riverbed was accreting in the period 1980-2002 (Dai and Liu, 2013). We thus conclude that the enhanced soil erosion from land use in the Changjiang basin could have partly mitigated the impact of dams and new artificial levees between 1971 and 2002 (Figs. 13A, 13B; see Dai et al., 2011a). These competing processes explain the mild decrease in SSC in the period 1971-2002 with respect to the period 1956-1970. Population growth and urbanization during these decades might have intensified soil erosion, although further research is needed to quantify this effect.

Since the start of operations of the TGD in 2003, many studies have investigated the influence of the dam on sediment discharge into the estuary (Xu and Milliman, 2009; Dai et al., 2014; Yang et al., 2015). The dam has trapped on average over $135 \times 10^{6}$ t of sediment every year between 2003 and 2013, resulting in more than $1500 \times 10^{6} \mathrm{t}$ of sediment sequestered in the reservoir since dam construction (Fig. 13C). Such a large volume of trapped sediments has had more impact on river dynamics than previous human activities in the catchment, despite that water discharge has not changed between 2003 and 2013 (Fig. 3B).

Moreover, we also noticed that water and soil conservation strategies have been implemented in the Changjiang River since the 1990s, leading to a decrease in soil erosion area from 0.62 million $\mathrm{km}^{2}$ in the 1980 s to 0.53 million $\mathrm{km}^{2}$ in 2008 (Liao, 2010). Such measures curb the loss of soil to a certain extent, further decreasing SSC in the river. Low SSC measured from 2003 to 2013 is mainly caused by large-scale sediment retention behind the TGD, which overrules the influence of water and soil conservation strategies. Furthermore, we can foresee that SSC will be further reduced as more dams, such as Xiluodu and Xiangjiaba, are constructed in the catchment (Fig. $1)$.

\section{Conclusions}

Variations in river SSC are not only a fundamental factor determining the amount of sediment discharged from the river into the sea but also a reflection of erosion/accretion dynamics in the watershed, affecting the global cycles of many 
elements. Here we show that SSC data collected at the head of the Changjiang River estuary in past decades display the following trends:

- The SSC in the Changjiang River between 1956 and 2013 exhibits a decline trend, which can be divided into the following periods: high SSC with mean value of 0.62 $\mathrm{kg} / \mathrm{m}^{3}$ between 1956 and 1970; relative high SSC with mean value of $0.42 \mathrm{~kg} / \mathrm{m}^{3}$ between 1971 and 2002; low SSC with mean value of $0.18 \mathrm{~kg} / \mathrm{m}^{3}$ between 2003 and 2013.

- Seasonal oscillations in SSC have also changed in recent decades. The typical regime of very high SSC of $0.69 \mathrm{~kg} / \mathrm{m}^{3}$ in the flood season and low SSC of 0.2 $\mathrm{kg} / \mathrm{m}^{3}$ in the dry season present between 1956 and 1970 changed to high SSC of $0.58 \mathrm{~kg} / \mathrm{m}^{3}$ in the flood season and low SSC of $0.15 \mathrm{~kg} / \mathrm{m}^{3}$ in the dry season in the period 1971-2002. After the TGD construction in 2003, the current regime is better described as low SSC of $0.19 \mathrm{~kg} / \mathrm{m}^{3}$ in the flood season and very low SSC of 0.09 $\mathrm{kg} / \mathrm{m}^{3}$ in the dry season. Moreover, the relationship between SSC and water discharge did not change between 1956 and 2002 but was altered following the establishment of the TGD in 2003, with high discharge events not characterized by high SSC and a lack of delay between peak in discharge and peak in SSC (lack of hysteresis).

- The SSC in the Changjiang River is dominated by discharge, deforestation, land use, soil erosion, and dam impoundment. Over the period ranging from 1956 to 2013, soil erosion induces high SSC, which gradually decreases because of the implementation of soil and water conservation strategies. On the other hand, dam impoundment leads to low SSC, and this effect has grown in time from the constructions of new dams. Large-scale deforestation in the Changjiang basin in the 1950s is responsible for soil erosion and very high SSC between 1956 and 1970. Sediment retention in small reservoirs and the blocking effect of new river levees has led to a small reduction in SSC between 1971 and 2002, while the extreme low SSC values measured after 2003 can be ascribed to the TGD construction.

\section{Acknowledgements}

This study was supported by the National Science Foundation of China (NSFC) (41576087; 51479074). We are grateful to the editor and two anonymous reviewers for their constructive comments and suggestions that improved the article. 


\section{References}

Allison, M.A., Demas, C.R., Ebersole, B.A., Kleiss, B.A., et al., 2012. A water and sediment budget for the lower Missippi-Atchafalaya River in flood years 20082010: implications for sediment discharge to the oceans and coastal restoration in Louisiana. Journal of Hydrology 432-433, 84-97.

Ballantine, D.J., Walling, D.E., Collins, A.L., Leeks, G.J.L., 2009. The content and storage of phosphorus in fine-grained channel bed sediment in contrasting lowland agricultural catchments in the UK. Geoderma 151, 141-9.

Bonsal, B.R., Zhang, X., Vincent, L.A., Hogg, W.D., 2001. Characteristics of daily and extreme temperatures over Canada. Journal of Climate 14 (9), 1959-1976.

Bulletin of China River Sediment (BCRS), 2001. Press of Ministry of Water Resources of the People's Republic of China. http://www.cjh.com.cn/.

Bulletin of China River Sediment (BCRS), 2014. Press of Ministry of Water Resources of the People's Republic of China. http://www.cjh.com.cn/.

Changjiang River Water Conservancy Committee (CRWCC), 2002. Changjiang River Almanac. Wuhan, Chiangjiang River Almanac Press.

Chen, X.Q., Yan, Y.X., Fu, R.S., Dou, X.P., Zhang, E.F., 2007. Sediment transport from the Yangtze River, China, into the sea over the post-Three Gorge Dam period: a discussion. Quaternary International 186, 55-64.

Chen, Z.Y., Wang, Z.H., Finlayson, B., Chen, J., Yin, D.W., 2010. Implications of flow control by the Three Gorges Dam on sediment and channel dynamics of the middle Yangtze (Changjiang) River, China. Geology 38(11), 1043-1046.

Dadson, S.J., Hovius, N., Chen, H.G., Dade, B., et al., 2003. Links between erosion, runoff variability and seismicity in the Taiwan orogeny. Nature 426, 648-651.

Dagg, M., Benner, R., Lohrenz, S., Lawrence, D., 2004. Transformation of dissolved and particulate materials on continental shelves influenced by large rivers: plume processes. Continental Shelf Research 24 (7-8), 833-858.

Dai, Z.J., Liu, J.T., 2013. Impacts of large dams on downstream fluvial sedimentation: an example of the Three Gorges Dam (TGD) on the Changjiang (Yangtze River). Journal of Hydrology 480, 10-18. 
Dai, Z.J., Chu, A., Stive, M.J.F., Du, J.Z., Li, J.F., 2011a. Is the Three Gorges Dam the cause behind the extremely low suspended sediment discharge into the Yangtze (Changjiang) estuary of 2006? Hydrological Sciences Journal 56 (7), 1280-1288.

Dai, Z.J., Chu, A., Stive, M.J.F., Zhang, X.L., Yan, H., 2011b. Unusual salinity conditions in the Yangtze Estuary in 2006: impacts of an extreme drought or of the Three Gorges Dam? AMBIO 40, 496-505.

Dai, Z.J., Du, J.Z., Zhang, X.L., Su, N., Li, J.F., 2011c. Variation of riverine martial loads and environmental consequences on the Changjiang estuary in recent decades. Environmental Science and Technology 45, 223-227.

Dai, Z.J., Liu, J.T., Wei, W., Chen, J.Y., 2014. Detection of the Three Gorges Dam influence on the Changjiang (Yangtze River) submerged delta. Scientific Reports 4, 6600, doi: 10.1038 .

Dai, Z.J., Liu, J.T., Xiang, Y.B., 2015. Human interference in the water discharge of the Changjiang (Yangtze River), China. Hydrological Sciences Journal 60:10, 1770-1782.

Eder, A., Strauss, P., Kruegger, T., Quinton, J.N., 2010. Comparative calculation of suspended sediment loads with respect to hysteresis effects (in the Petzenkirchen catchment, Austria). Journal of Hydrology 389, 168-176.

Ferguson, R.I., 1986. River loads underestimated by rating curves. Water Resources Research 22: 74-76.

Frihy, O.E., Dewidar, K.M., El Banna, M.M., 1998. Natural and human impact on the northeastern Nile delta coast of Egypt. Journal of Coastal Research 14, 1109-1118.

Greenwood, J.A., Landwehr, J.M., Matalas, N.C., Wallis, J.R., 1979. Probability weighted moments: definition and relation to parameters of distribution expressible in inverse form. Water Resources Research 15(5), 1049-1054.

Greig, S.M., Sear, D.A., Carling, P.A., 2005. The impact of fine sediment accumulation on the survival of incubating salmon progeny: implications for sediment management. Science of Total Environment 344, 241-58.

Gao, S., Wang, Y.P., 2008. Changes in material fluxes from the Changjiang River and their implications on the adjoining continental shelf ecosystem. Continental Shelf 
Research 28 (12), 1490-1500.

Heywood, M.J.T., Walling D.E., 2007. The sedimentation of salmonid spawning gravels in the Hampshire Avon catchment, UK: implications for the dissolved oxygen content of intragravel water and embryo survival. Hydrological Processes $21,770-88$.

Horowitz, A.J., 2003. An evaluation of sediment rating curves for estimating suspended sediment concentrations for subsequent flux calculations. Hydrological Processes 17, 3387-3409.

Horowitz, A.J., Elrick, K.A., Smith, J.J., 2001. Estimating suspended sediment and trace element fluxes in large river basins: methodological considerations as applied to the NASQAN programme. Hydrological Processes 15, 1107-1132.

Huang, W., 2010. Hydrodynamic modeling and eco-hydrological analysis of river inflow effects on Apalachicola Bay, Florida, USA. Estuarine, Coastal, and Shelf Science 86 (3), 526-534.

Intergovernmental Panel on Climate Change (IPCC), 2007. In: Solomon, S., et al. (Eds.), Climate Change 2007: the Physical Science Basi-Contribution of Working Group I to the Fourth Assessment Report of the Intergovernmental Panel on Climate Change. Cambridge Univ. Press, Cambridge, U. K, pp. 663-745.

Kettner, A.J., Gomez, B., Syvitski, J.P.M., 2007. Modeling suspended sediment discharge from the Waipaoa River system, New Zealand: the last 3000 years. Water Resources Research 43, W07411, doi: 10.1029/2006WR005570.

Kronvang, B., Laubel, A., Grant, R., 1997. Suspended sediment and particulate phosphorus transport and delivery pathways in an arable catchment, Gelbaek stream, Denmark. Hydrological Processes 11, 627-642.

Liang, Y., Shi, X.Z., Shi, D.M., 1998. Analysis on flood in 1998 based on water and soil erosion and the storage capacity of soil water. Chinese Water and Soil Conservation 11, 32-34 (In Chinese).

Liao, C.Y., 2010. Prospect and review of soil and water conservation in the Changjiang basin in recent 60 years. Yangtze River 41 (4), 26-30 (In Chinese). 
Liu, J.P., Xu, K.H., Li, A.C., Milliman, J.D., Velozzi, D.M., Xiao, S.B., Yang, Z.S., 2007. Flux and fate of Yangtze river sediment delivered to the East China Sea. Geomorphology 85, 208-224.

Meade, R.H., Moody, J.A., 2010. Causes for the decline of suspended-sediment discharge in the Mississippi River system, 1940-2007. Hydrological Processes 24, $35-49$.

Megnounif, A., Terfous, A., Ouillon, S., 2013. A graphical method to study suspended sediment dynamics during flood events in the Wadi Sebdou, NW Algeria (19732004). Journal of Hydrology 497, 24-36.

Milliman, J.D., Boyle, E.A., 1975. Biological uptake of dissolved silica in the Amazon River estuary. Science 189, 995-997.

Milliman, J.D., Farnsworth, K.L., 2011. River Discharge to the Coastal Ocean-A Global Synthesis. Cambridge, UK: Cambridge University Press, p.392.

Mouri, G., Ros, F.C., Chalov, S., 2014. Characteristics of suspended sediment and river discharge during the beginning of snowmelt in volcanically active mountainous environments. Geomorphology 213, 266-276.

Phillips, J.M., Webb, B.W., Walling, D.E., Leeks, G.J.L., 1999. Estimating the suspended sediment loads of rivers in the LOIS study area using infrequent samples. Hydrological Processes 13, 1035-1050.

Quinn, J., Davies-Colley, R., Hickey, C., Vickers, M., Ryan, P., 1992. Effects of clay discharges on streams. Hydrobiologia 248, 235-47.

Quinton, J.N., Catt, J.A., Hess, T.M., 2001. The selective removal of phosphorus from soil. Journal of Environmental Quality 30, 538-45.

Rondeau, B., Cossa, D., Gagnon, P., Bilodeau, L., 2000. Budget and sources of suspended sediment transported in the St. Lawrence River, Canada. Hydrological Processes 14, 21-36.

Rovira, A., Batalla, R.J., 2006. Temporal distribution of suspended sediment transport in a Mediterranean basin: the lower Tordera (NE Span). Geomorphology 79, 5871. 
Shi, D.M., 1999. Analysis of relationship between soil and water loss and flood disasters in Yangtze River basin. Journal of Soil Water conservance 5, 1-7 (In Chinese with an English abstract).

Siakeu, J., Oguchi, T., Aoki, T., Esaki, Y.J., Jarvie, H.P., 2004. Change in riverine suspended sediment concentration in central Japan in response to late 20th century human activities. Catena 55, 231-254.

Sickle, J. V., Beschta, R.L., 1983. Supply-Based Models of Suspended Sediment Transport in Streams. Water Resources Research 19(3), 768-778.

Steegen, A., Govers, G., Nachtergale, J. et al., 2000. Sediment Export by Water from an Agricultural Catchment in the Loam Belt of Cen-tral Belgium. Geomorphology 33 (1-2), 25-36.

Syvitski, J.P.M., Vörösmarty, C.J., Kettner, A.J., Green, P., 2005. Impact of humans on the flux of terrestrial sediment to the global coastal ocean. Science 308 (15), 376380.

Terfous, A., Megnounif, A., Bouanani, A., 2001. Study of the suspended load at the river Mouilah (north west Algeria). Revue Des Sciences De L Eau 14 (2), 173 185.

Vörösmarty, C.J., Meybeck, M., Fekete, B., Sharma, K., Green, P., Syvitski, J.P.M., 2003. Anthropogenic sediment retention: major global impact from registered river impoundments, Global Planet. Change 39, 169-190.

Walling, D.E., 1977. Assessing the accuracy of suspended sediment rating curves for a small basin. Water Resources Research 12: 1869-1894.

Walling, D.E., 1997. Assessing the Accuracy of Suspended Sediment Rating Curves for a Small Basin. Water Resources Research 13 (3), 531-538.

Walling, D.E., 2006. Human impact on land-ocean sediment transfer by the world's rivers. Geomorphology 79, 192-216.

Walling, D.E., Fang, D., 2003. Recent trends in the suspended sediment loads of the world rivers. Global and Planetary Change 39, 111-126. 
Walling, D.E., Owens, P.N., Leeks, G.J.L., 1999. Fingerprinting suspended sediment sources in the catchment of the River Ouse, Yorkshire, UK. Hydrological Processes 13, 955-975.

Wang, H. J., Yang, Z. S., Saito, Y., Liu, P. J., Sun, X. X., Wang, Y., 2007. Stepwise decrease of the Huanghe Yellow River) sediment load (1950-2005): impacts of climate change and human activities. Global and Planetary Change 57, 331-354.

Wass, P., Leeks, G.J.L., 1999. Suspended sediment fluxes in the Humber catchment, UK. Hydrological Processes 13, 935-953.

Wei, W., Chang, Y.P., Dai, Z.J., 2014. Streamflow changes of the Changjiang (Yangtze) River in the recent 60 years: impacts of the East Asian summer monsoon, ENSO, and human activities. Quaternary International 336, 98-107.

Wood, P.A., 1977. Controls of variation in suspended sediment concentration in the river Rother, West Sussex, England. Sedimentology 24, 437-445.

Xu, K.H., and Milliman, J.D., 2009. Seasonal variations of sediment discharge from the Yangtze River before and after impoundment of the Three Gorges Dam. Geomorphology 104, 276-283.

Yamada H, Nakamura F., 2002 Effect of fine sediment deposition and channel works on periphyton biomass in the Makomanai River, northern Japan. River Research Application 18, 481-93.

Yang, G.F., Chen, Z.Y., Yu, F.L., Wang, Z.H., Zhao, Y.W., Wang, Z.Q., 2007. Sediment rating parameters and their implications: Yangtze River, China. Geomorphology 85, 166-175.

Yang, S.L., Shi, Z., Zhao, H.Y., Li, P., Dai, S.B., Gao, A., 2004. Effects of human activities on the Yangtze River suspended sediment flux into the estuary in the last century. Hydrology and Earth System Sciences 8 (6), 1210-1216.

Yang, S.L., Xu, K.H., Milliman, J.D, Yang, H.F., Wu, C.S., 2015. Decline of Yangtze River water and sediment discharge: impact from natural and anthropogenic changes. Scientific Reports 5, 12581, doi. 1038/srep12581. 
Yang, S.L., Zhao, Q.Y., Belkin, I.M., 2002. Temporal variation in the sediment load of the Yangtze river and the influences of human activities. Journal of Hydrology $263,56-71$.

Zhang, Q., Xu, C.Y., Jiang, T., Wu, Y.J., 2007. Possible influence of ENSO on annual maximum stream of the Yangtze River, China. Journal of Hydrology 333, 265274.

Zhang, S., Zhu, C., 2001. Soil loss and its effect on flooding catastrophe in Yangtze drainage basin. Journal of Soil Water Conservancy 15, 9-16 (In Chinese with English abstract). 


\section{Figure captions:}

Fig. 1. Changjiang catchment and location of the hydrological gauging station (green triangle) and river dams (circles).

Fig. 2. Long-term changes in suspended sediment discharge (SSD) and suspended sediment concentration (SSC). (A) Changes in SS); (B) Changes in SSC. The values $0.62,0.42,0.18 \mathrm{~kg} / \mathrm{m}^{3}$ represent the yearly mean in SSC for the periods 1956-1970, 1971-2002, and 2003-2013, respectively. The $25^{\text {th }}$ and $75^{\text {th }}$ percentiles are also indicated.

Fig. 3. Long-term variations in (A) average annual precipitation and (B) average annual water discharge

Fig. 4. Sedimentological parameters at Datong station as a function of time ((A) The 25th percentile of daily SSC; (B) The 75th percentile of daily SSC; (C) The standard deviation of daily SSC; (D) Coefficient of variation, $\mathrm{Cv}$; (E) yearly maximum of SSC).

Fig. 5. Average monthly maximum SSC for different time periods.

Fig. 6. Monthly averages of SSC (A), water discharge (B), and SSD (C).

Fig.7. Frequency of daily SSC binned in $0.05 \mathrm{~kg} / \mathrm{m}^{3}$ intervals for different time periods (A) 1956-1970; (B) 1971-2002; (C) 2003-2013).

Fig. 8. Rating curves of monthly water discharge versus monthly SSC. The numbers represent the calendar months.

Fig. 9. Relationships between daily SSC and daily water discharge: (A) 1956-1970; (B) 1971-2002; (C) 2003-2013).

Fig. 10. (A) Relation between water discharge and precipitation in the period 19562012; (B) relation between SSC and water discharge in 1956-1970; (C) relation between SSC and water discharge in 1971-2002; (D) relation between SSC and water discharge in 2003-2013.

Fig. 11. Daily SSC and water discharge in different flood years: A) 1964; (B) 1973; (C) 1983; (D) 1998; (E) 2010.

Fig. 12. Daily SSC and water discharge during different drought years: (A) 1963; (B) 1978; (C) 2011.

Fig. 13. Anthropogenic activities in the catchment: (A) total capacity of reservoirs in the catchment as a function of time; (B) total length of new levees; (C) volume of sediments trapped behind the TGD. 


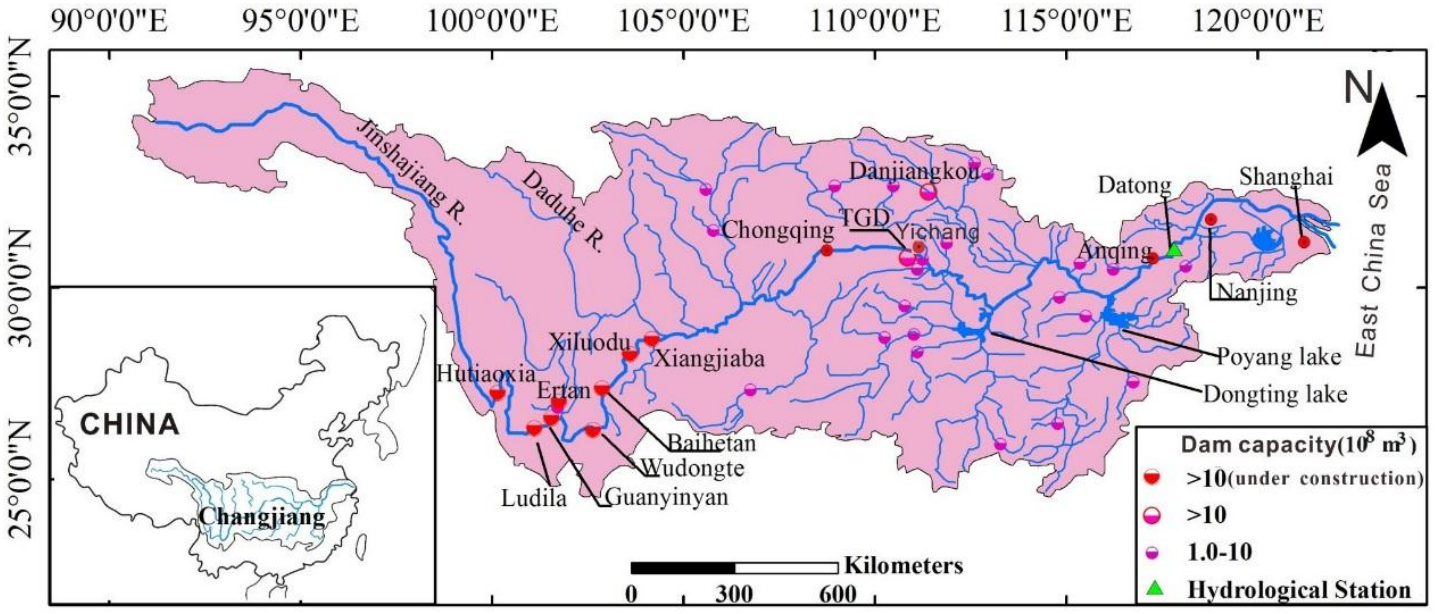



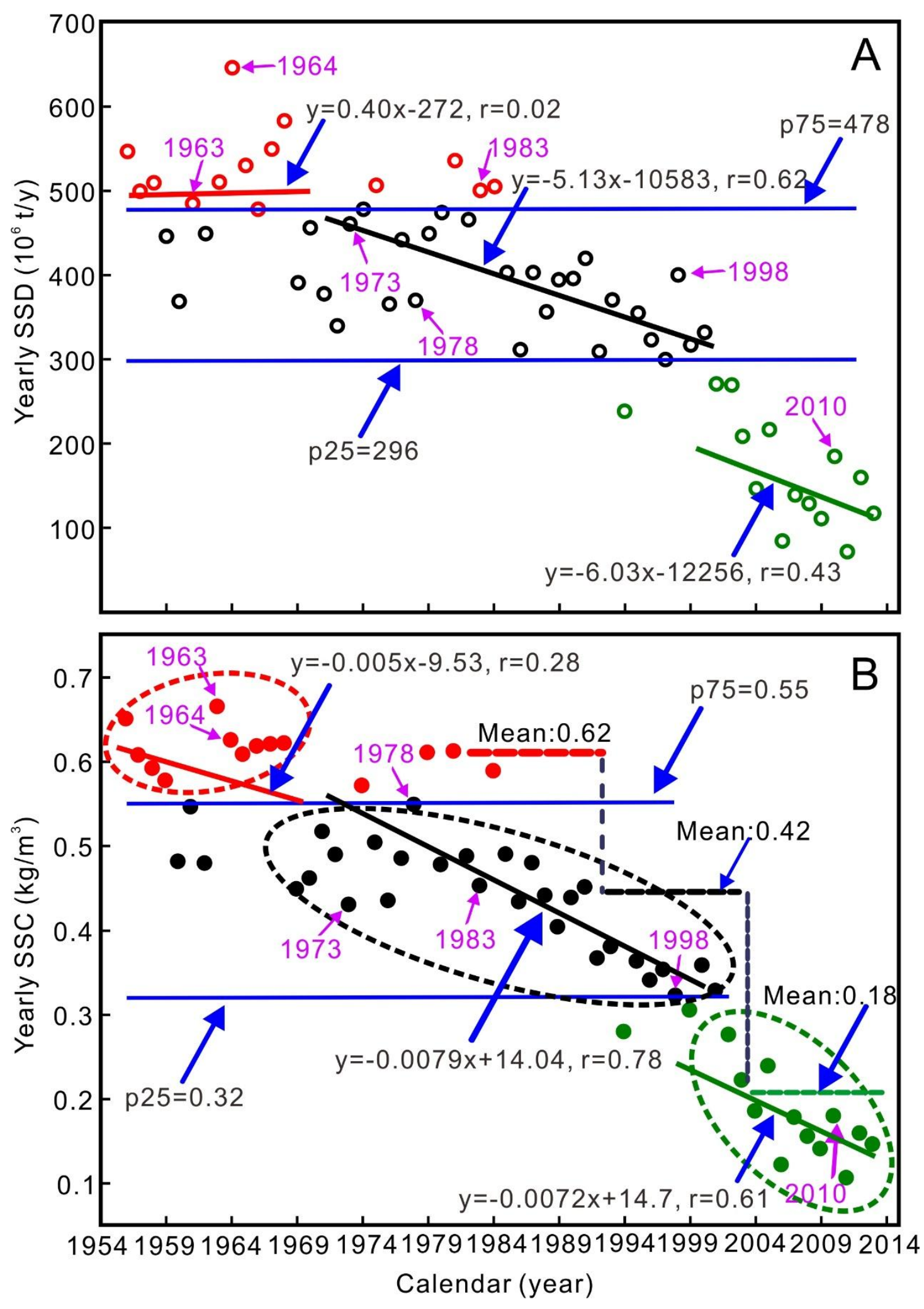


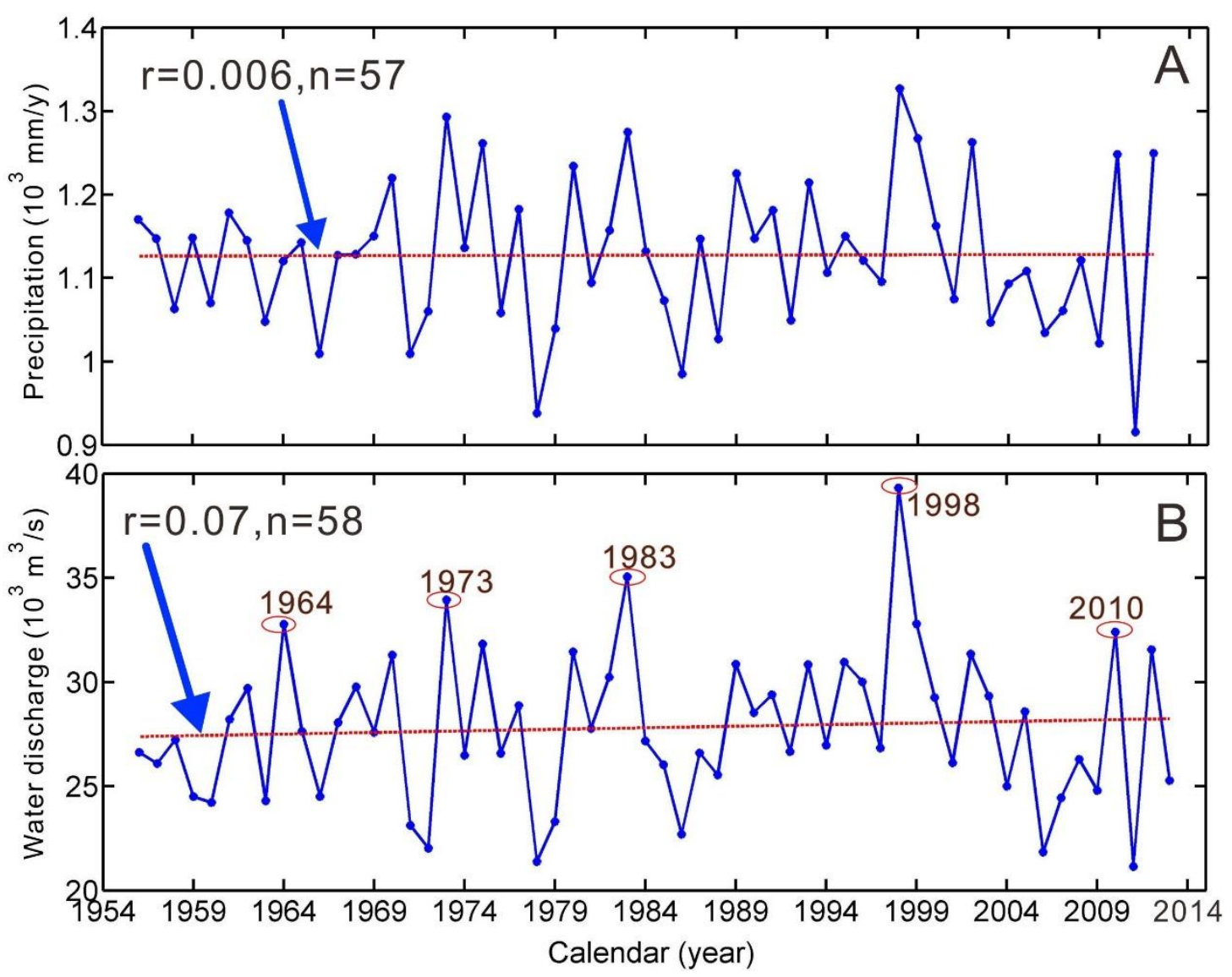



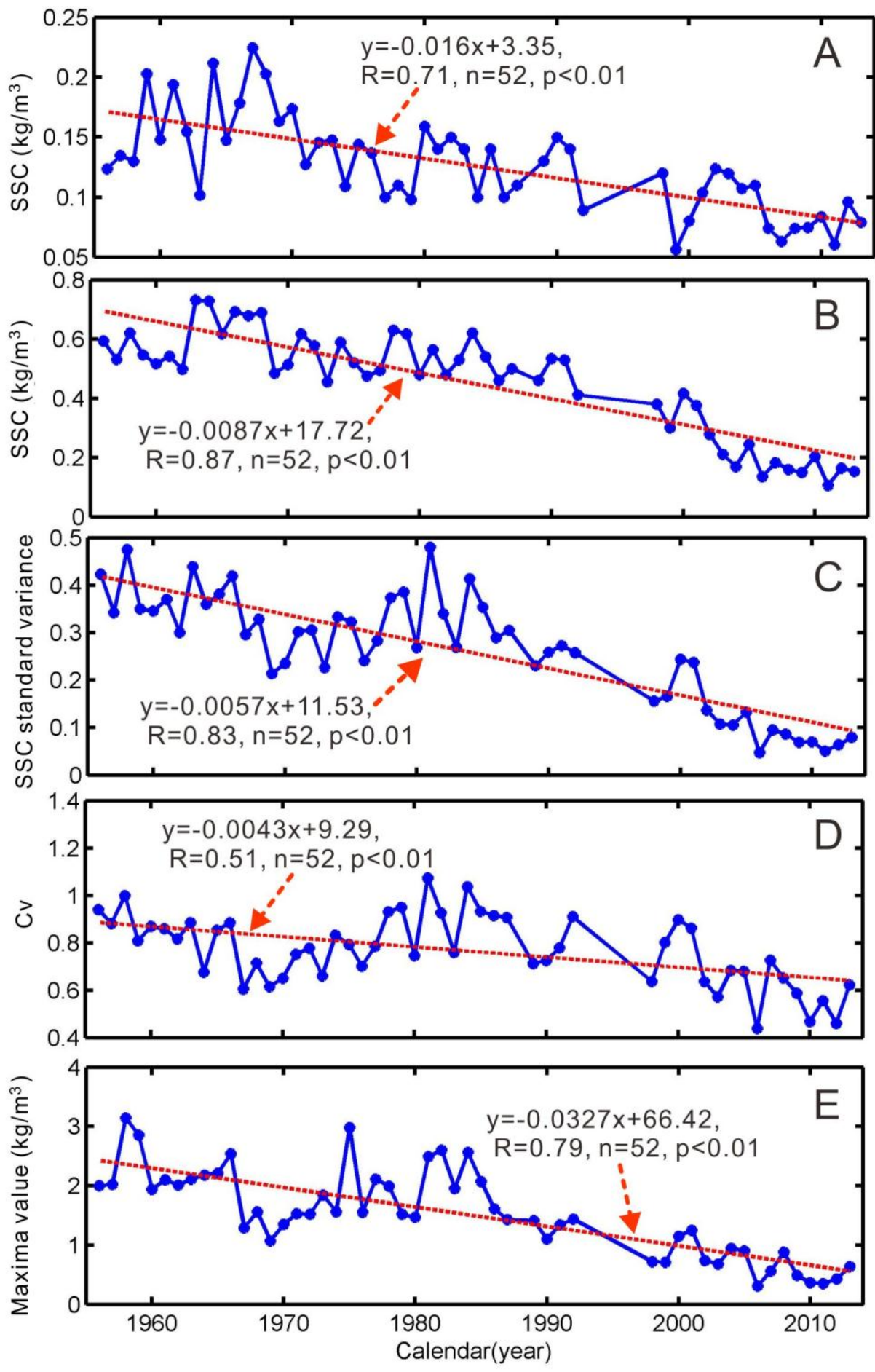


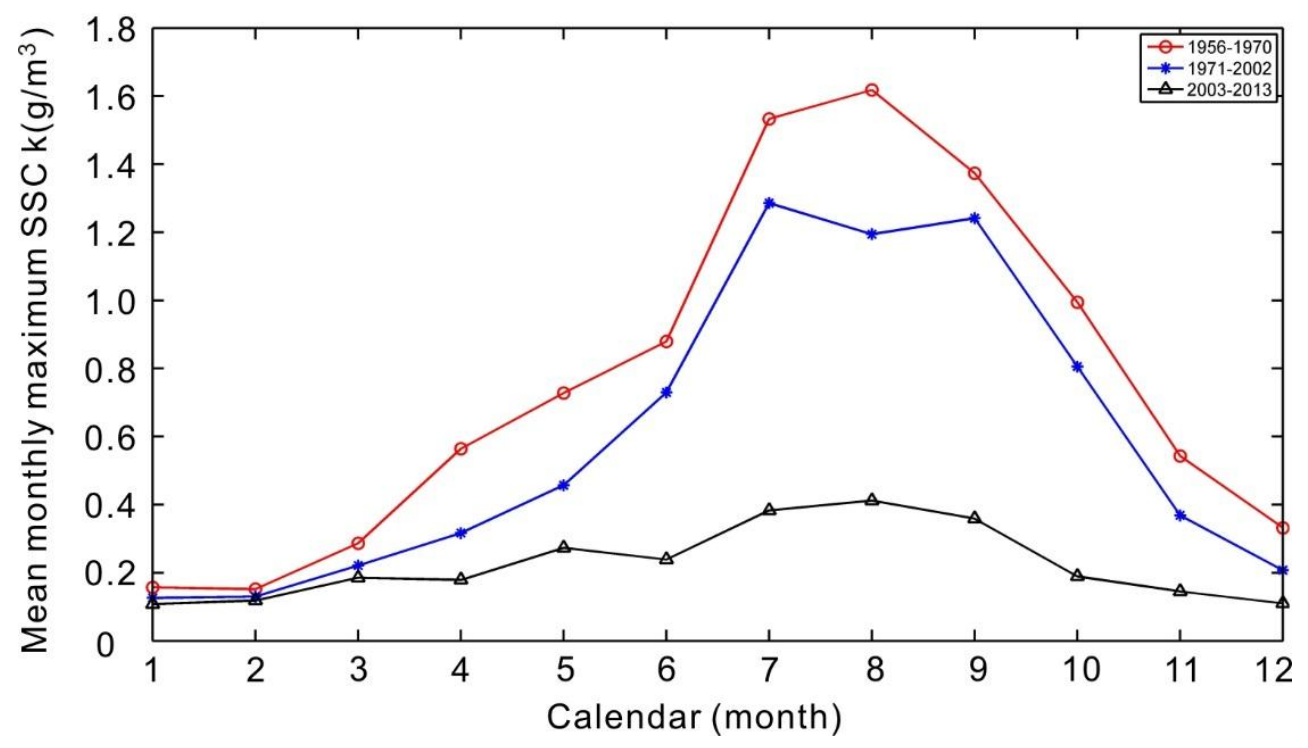



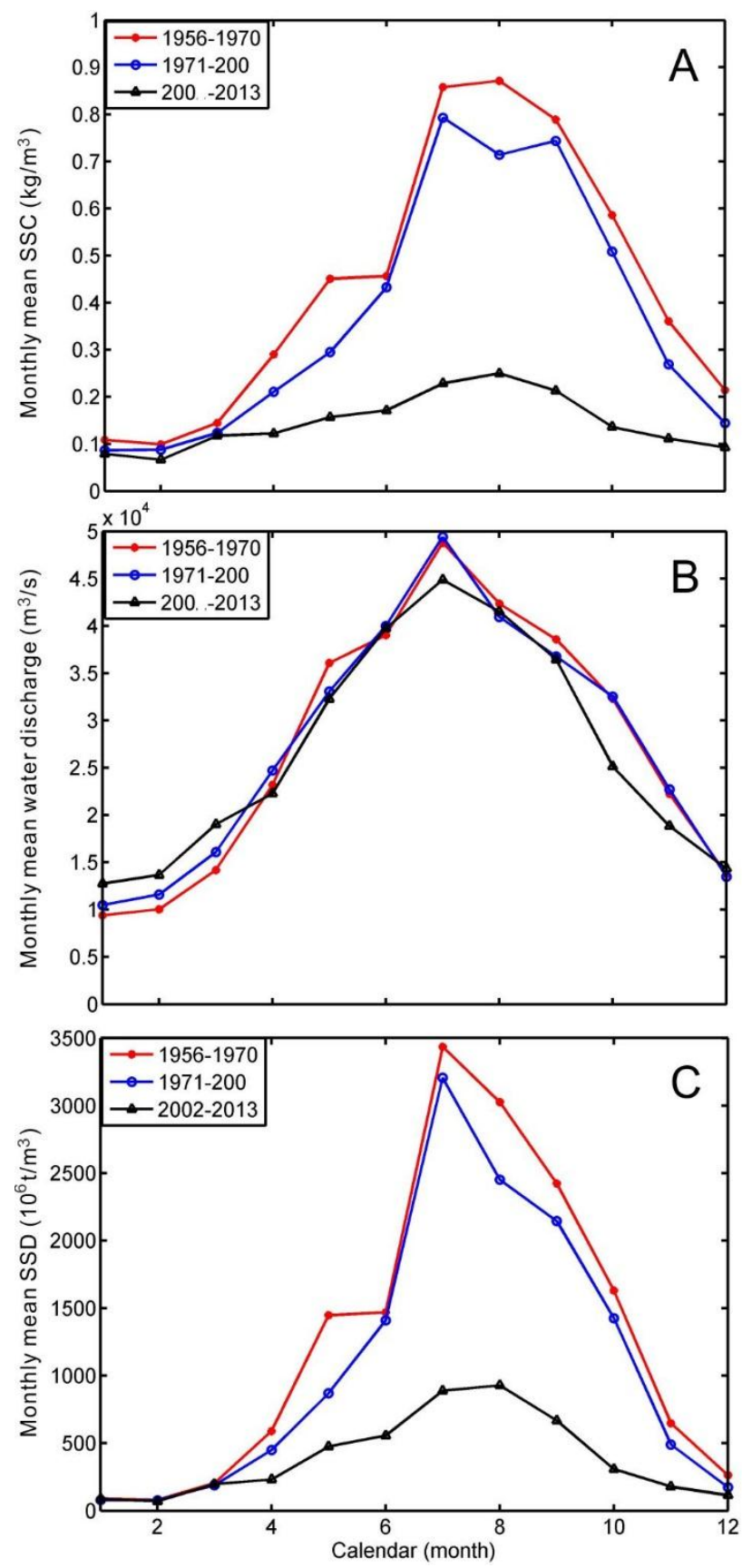


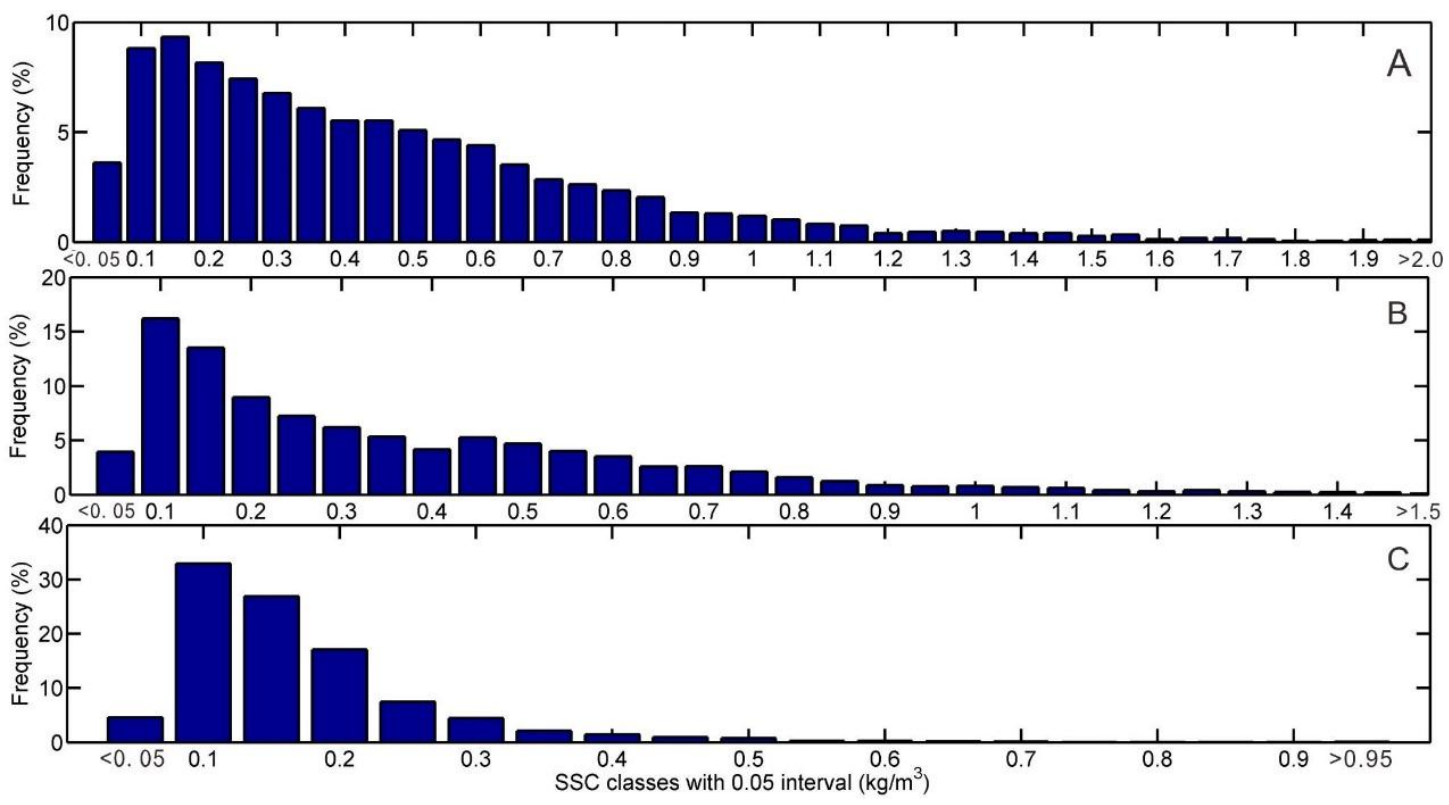




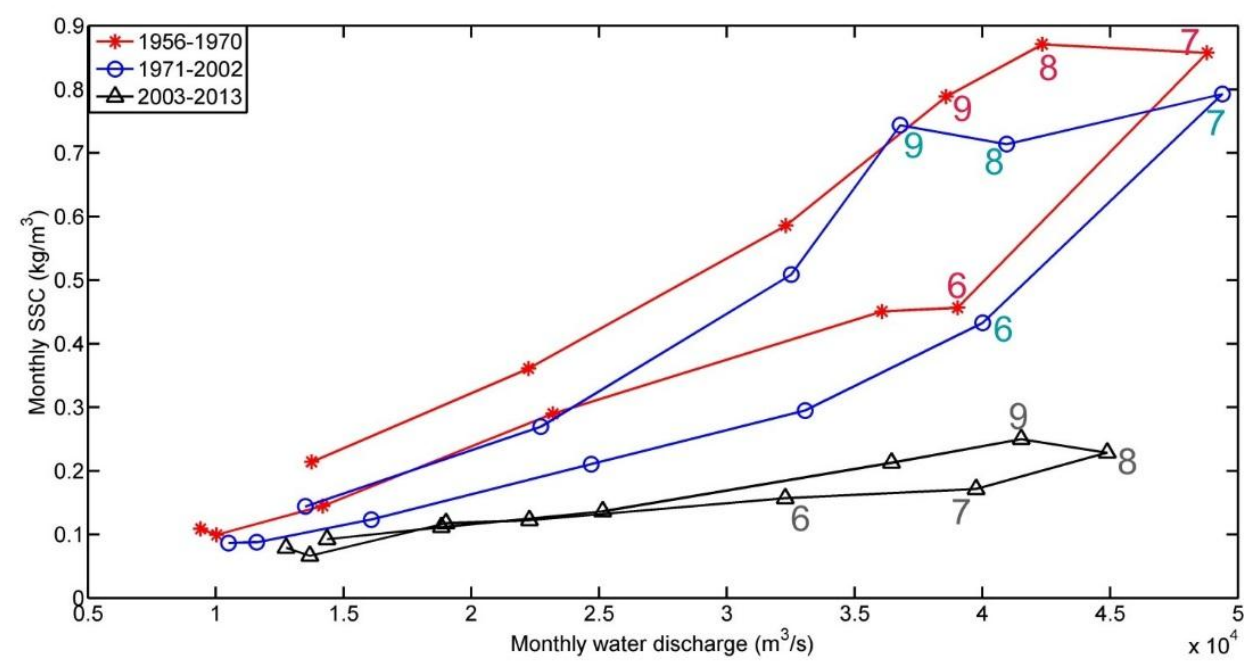



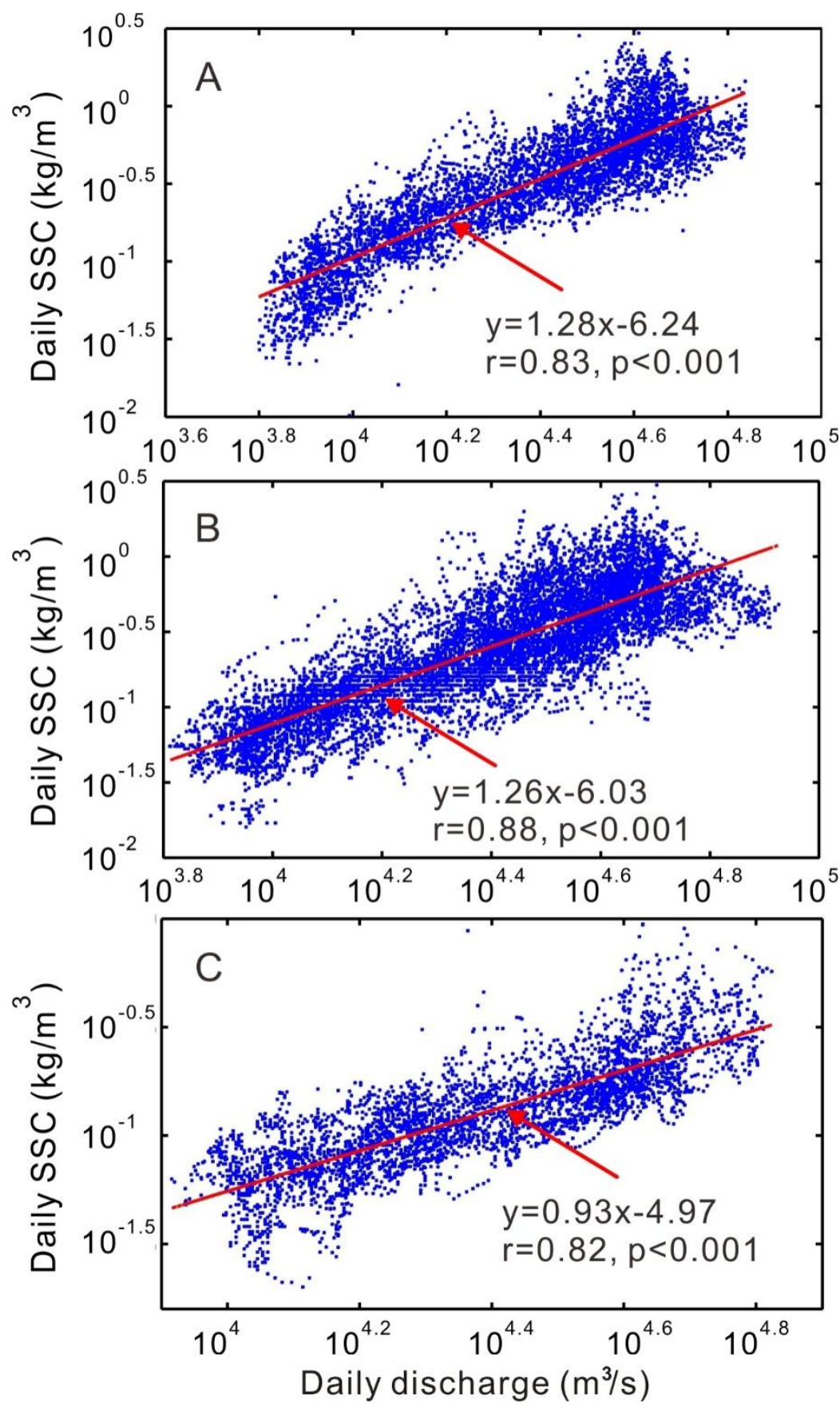

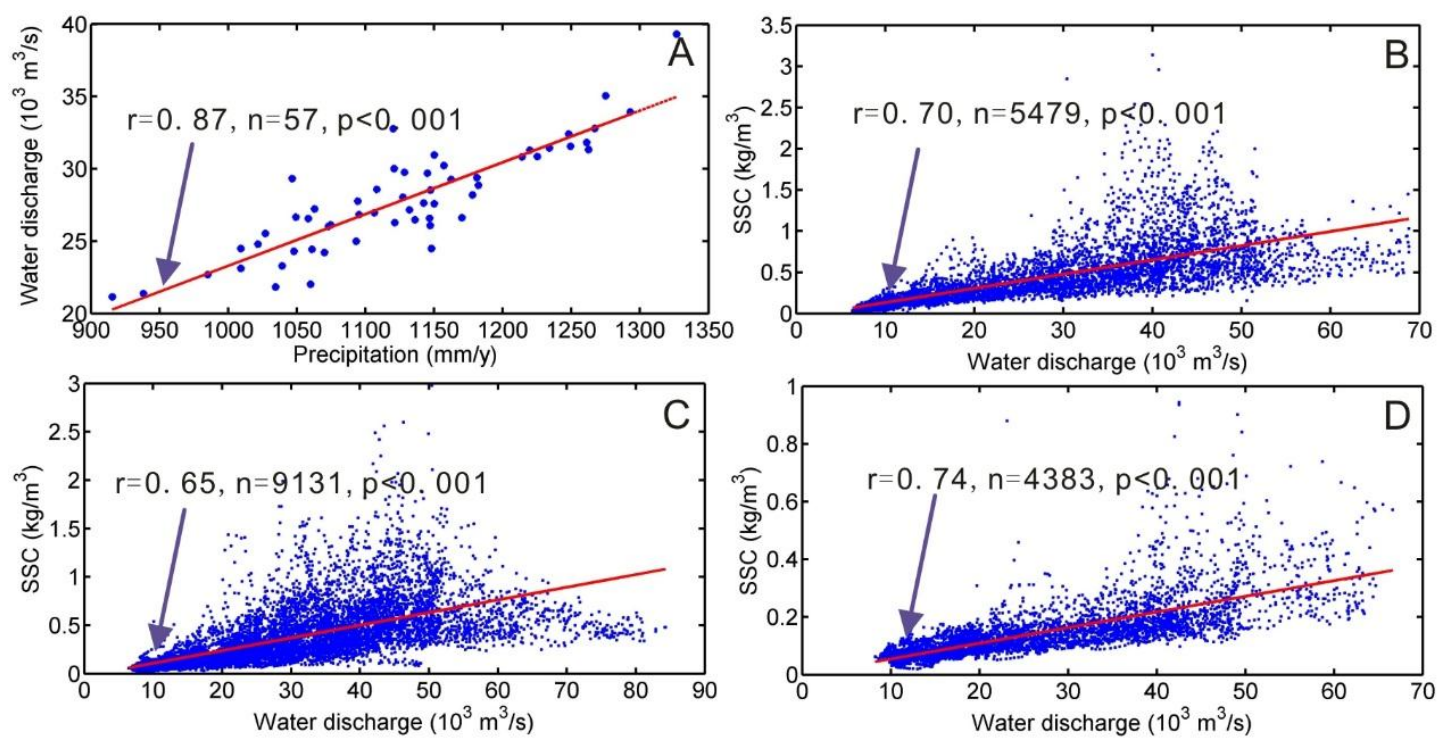

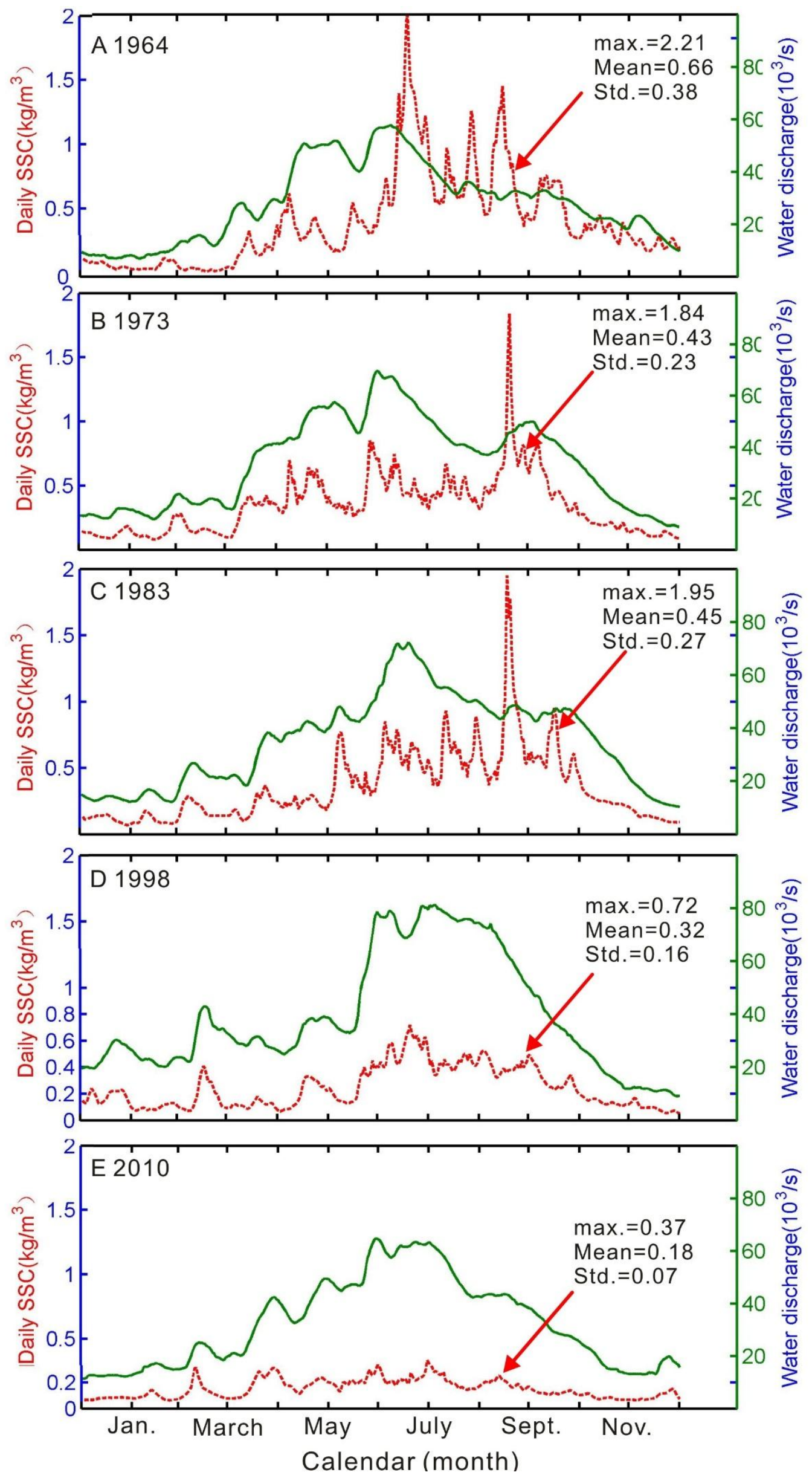


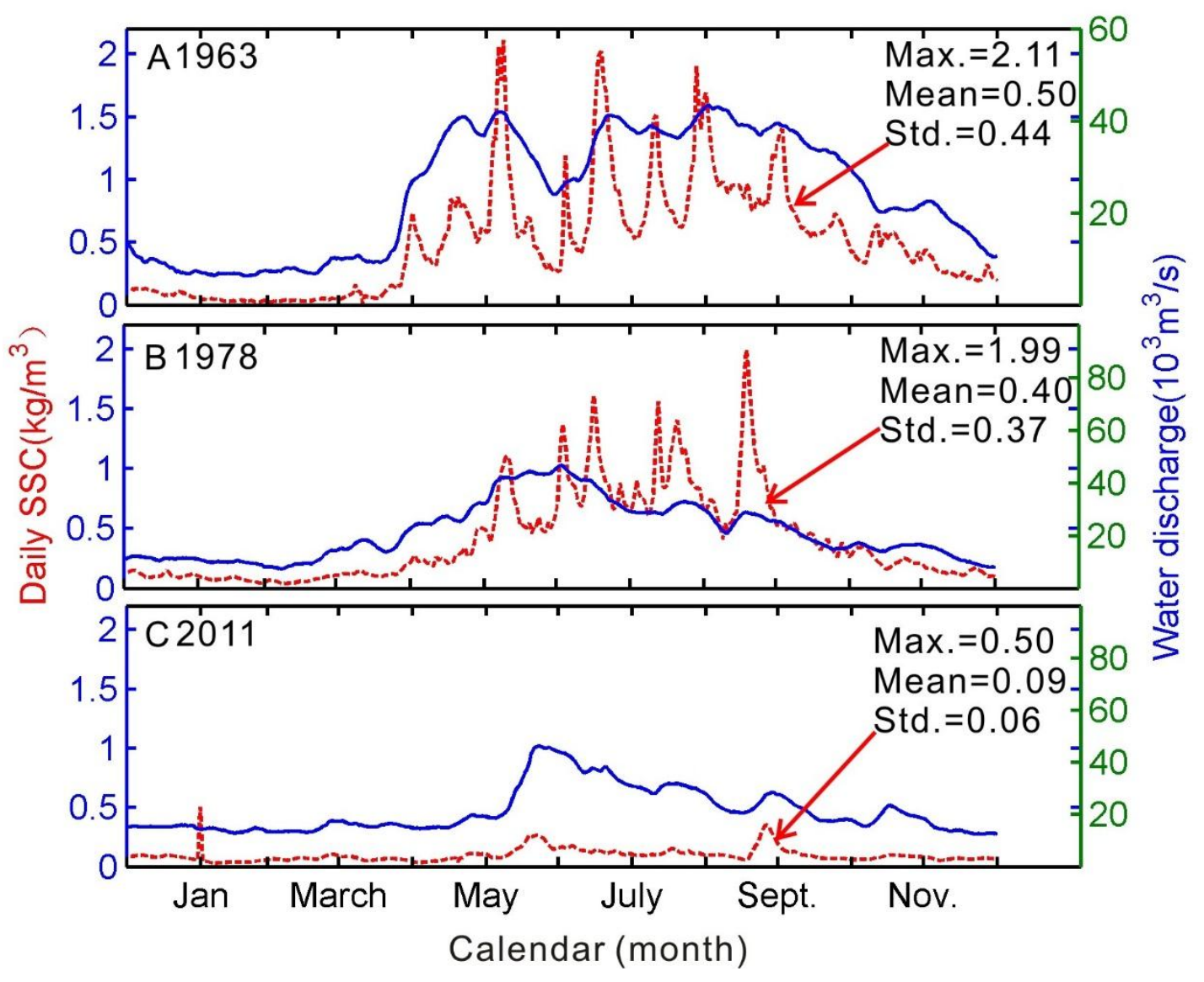



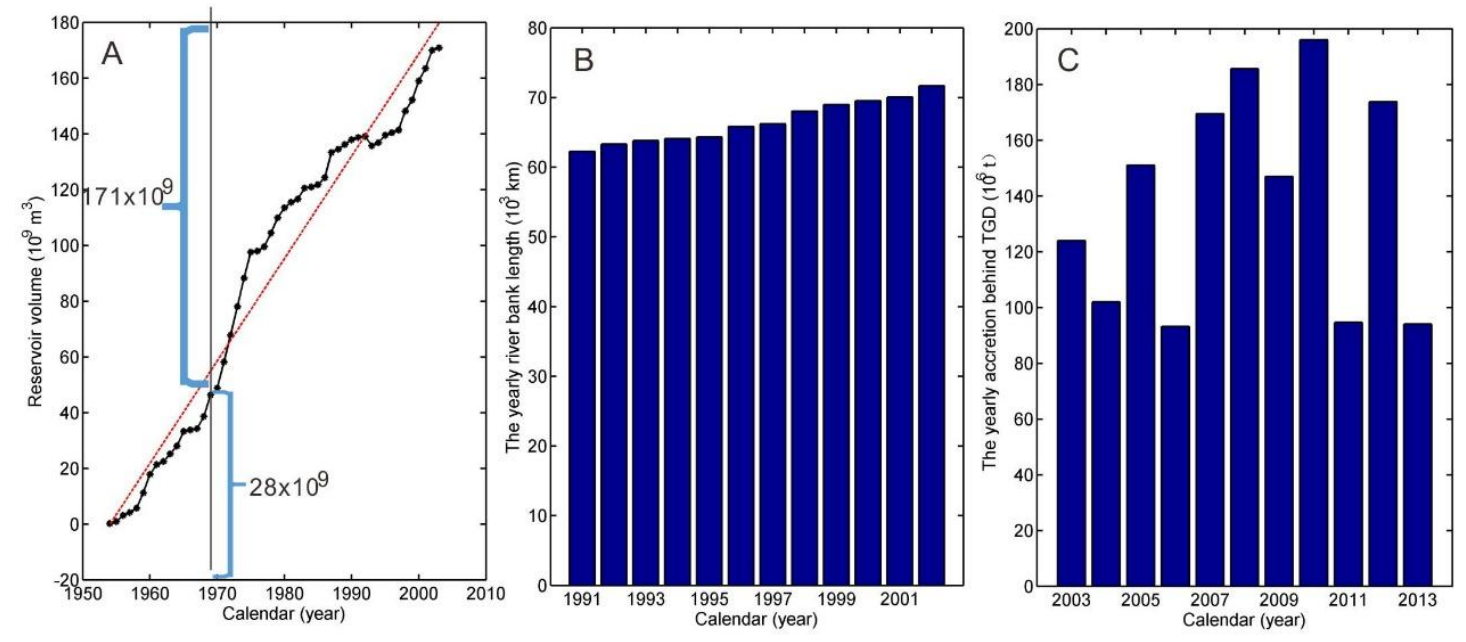

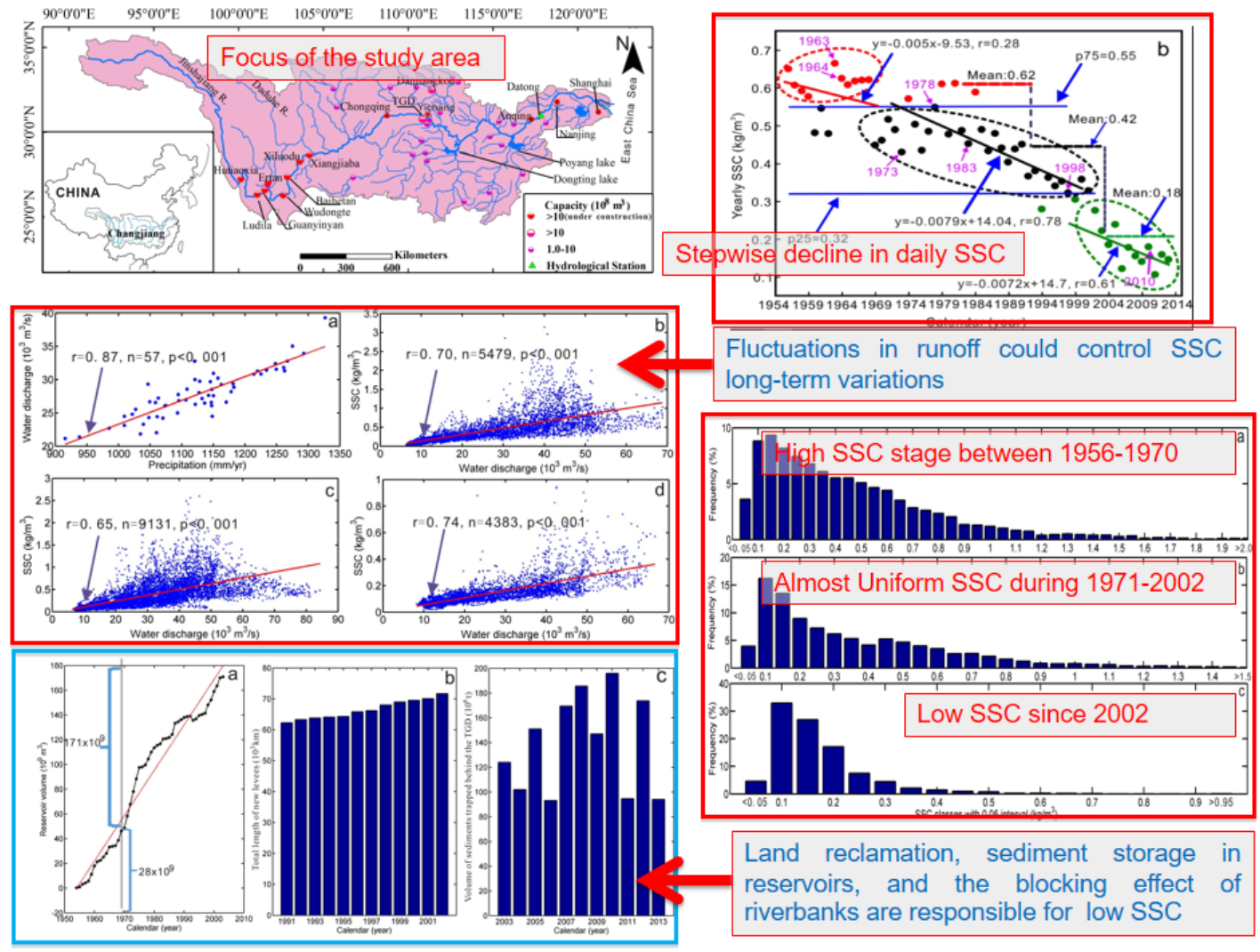